\title{
Biogas Production and Optimization from Leftover Food and Solid Kitchen Wastes
}

\author{
Desalegn Abdissa Akuma \\ School of Chemical Engineering, Jimma University / Jimma Technology Institute, Jimma City, Ethiopia
}

\section{Email address:}

abdissa694@gmail

\section{To cite this article:}

Desalegn Abdissa Akuma. Biogas Production and Optimization from Leftover Food and Solid Kitchen Wastes. Science Research. Vol. 8, No. 1, 2020, pp. 20-30. doi: 10.11648/j.sr.20200801.14

Received: September 23, 2019; Accepted: April 1, 2020; Published: April 28, 2020

\begin{abstract}
Food leftover and solid kitchen waste disposed on open land surface, consequences different problems like air pollution, human health problem, ground water pollution, disturbance of ecosystem etc. For this problem recovering leftover food and solid kitchen waste for biogas production is critical solution. Sustainable energy production is the current issue for non renewable energy crises. The quality biogas determined by factors (temperature, PH, retention time and substrates). The method that determines the quality and quantity of biogas: first Data (leftover food and solid kitchen waste) was collected, characterize, then the slurry solution where prepared. At $\mathrm{pH}$ of solution (slurry) adjusted $4.6-6.3$, at the temperature of Mesophilic range $25-40^{\circ} \mathrm{C}$ ). The biogas production procedure: Hydrolysis - Acidogenesis - Acetogenesis - Methanogenesis. the volumew of biogas and $\mathrm{CH}_{4}$ maximization is the objective of this syudies. depending on experiental result output optimization model equation was developed using design expert, central composite method. In this experimental design With the retention time of 29 days, the quality is tested at an different alternatives. From the substrate source of leftover food and solid kitchen wastes, using experimental input, optimization result output from design expert: $63.3 \% \mathrm{CH}_{4}, 27.9 \% \mathrm{CO}_{2}, 0.316 \%$ $\mathrm{O}_{2}$ and $3.35 \mathrm{~L}$ biogas quality and quantity respectively produced, from $1.75 \mathrm{~L}$ of proportional slurry substrate prepared, at temperature $26.1^{\circ} \mathrm{C}$ and $\mathrm{pH} 5.51$.
\end{abstract}

Keywords: Biogas, Digester, Methane, Carbon Dioxide, Substrate, Temperature, Slurry, Quality, Optimization

\section{Introduction}

Sustainable energy production is the most current issues over the world wide, non renewable energy (petroleum, natural gas, fossil fuel and others) are depilated from time to time and going to eliminates [1]. In other ways the output consumption of the non renewable energy affects natural environmental ecosystem by releasing excess oxide to the environment [1]. Biogas is a combustible mixture of gases and an eco-friendly heating energy sources [2]. It consists mainly of methane $\left(\mathrm{CH}_{4}\right)$ and carbon dioxide $\left(\mathrm{CO}_{2}\right)$ and is formed from the anaerobic bacterial decomposition of organic compounds, in the absence of oxygen [3]. The gases formed are the waste products of the respiration of these decomposer microorganisms and the composition of the gases depends on the feedstock being decompose [4]. Substrate types also influences the product of biogas. If the substrate consists of mainly carbohydrates, such as glucose and other simple sugars and high-molecular compounds (polymers) such as cellulose and hemicelluloses, the methane production is low, However, if the fat content is high, the methane production is high. Methane and whatever additional hydrogen there may be makes up the combustible part of biogas [5]. Methane is a colorless and odorless gas with a boiling point of $-162^{\circ} \mathrm{C}$ that burns with a blue flame [6]. Methane is also the main constituent (77-90\%) of natural gas) [7]. Biogas is a renewable fuel, so it qualifies for sustainable energy subsidies in some parts of the world, Biogas can also be cleaned and upgraded to natural gas standards when it becomes bio methane [8]. Biogas consists of 55-70 $\mathrm{CH}_{4}, 30-45$ $\mathrm{CO}_{2}, 0-2 \% \mathrm{H}_{2} \mathrm{~S}$ and may small amount trace element or compound [9]. At normal temperature and pressure, methane has a density of approximately $0.75 \mathrm{~kg} / \mathrm{m}^{3}$. Due to carbon dioxide is somewhat heavier, biogas has a slightly higher density $\left(1.15 \mathrm{~kg} / \mathrm{m}^{3}\right)$. Pure methane has an average calorific value of ranged between 10.7 and $13.0 \mathrm{MJ} / \mathrm{kg}$, which correspond to $11.06 \mathrm{kWh} / \mathrm{m}^{3}$. If biogas is mixed with $10-20 \%$ air, you get explosive air, which as the name indicates is explosive. Biogas is about $20 \%$ lighter than air and has an 
ignition temperature in the range of $650^{\circ} \mathrm{C}$ to $750^{\circ} \mathrm{C}$. It is odour less and color less gas that burns with clear blue flame. Its caloric value is $20 \mathrm{Mega}$ Joules $(\mathrm{MJ}) / \mathrm{m}^{3}$ and burns with $60 \%$ efficiency in a conventional biogas stove [10].

\section{Materials and Methods}

\subsection{Materials}

Weight measuring instrument: to determine the weight of food waste and kitchen waste samples, Oven dryer base: to measure moisture content, Mixer cylinder, Miller: to make substrate homogeneous, $\mathrm{pH}$ meter: to check acidity, Anaerobic batch digester tank, Food \& kitchen waste, Fresh cow dung used as inoculums, Mixing tank used to mix water and food \& kitchen waste, Measuring cylinder, pipe, valve, sodium hydroxide, Gas collector or bellow.

\subsection{Methods}

The method was experimental laboratory result analysis and software programming optimization. The biogas quality was analyzed at every alternative factor by using biogas analyser. To produce high quality and high quantity of biogas: temperature, $\mathrm{PH}$ and retention time are the basic measurements (factors) [11]. First food and kitchen wastes were weighted using weight measuring instrument. Homogenise the wastes and dilute with proportional at dilution rate of 1: 1.5 with water [12]. Check the composition ( $\mathrm{C} / \mathrm{N}$ ratio is $25: 1$ to $30: 1$ ) [13]. The $\mathrm{pH}$ of solution (slurry) adjusted at standard production rate $(\mathrm{pH} 4.5-7)$, at the temperature of Mesophilic range $20-40^{\circ} \mathrm{C}$ ) [14] The sample where first mixed with water and inoculums and completely stirred until homogenized. The prepared slurry input to an aerobic Digester tank (batch reactor), and kept them it there until reaction completed (residence time or hydraulic retention time $20-40$ days). In this parameter ranges biogas quality product estimates $\mathrm{CH}_{4} 50 \%-75 \%$ and $\mathrm{CO}_{2}$ is $25 \%$ $45 \%$ [15] Collect top products or biogas to gas collector and measure appropriately. Collect sludge and water in bottom product by different stream in (figure 1).

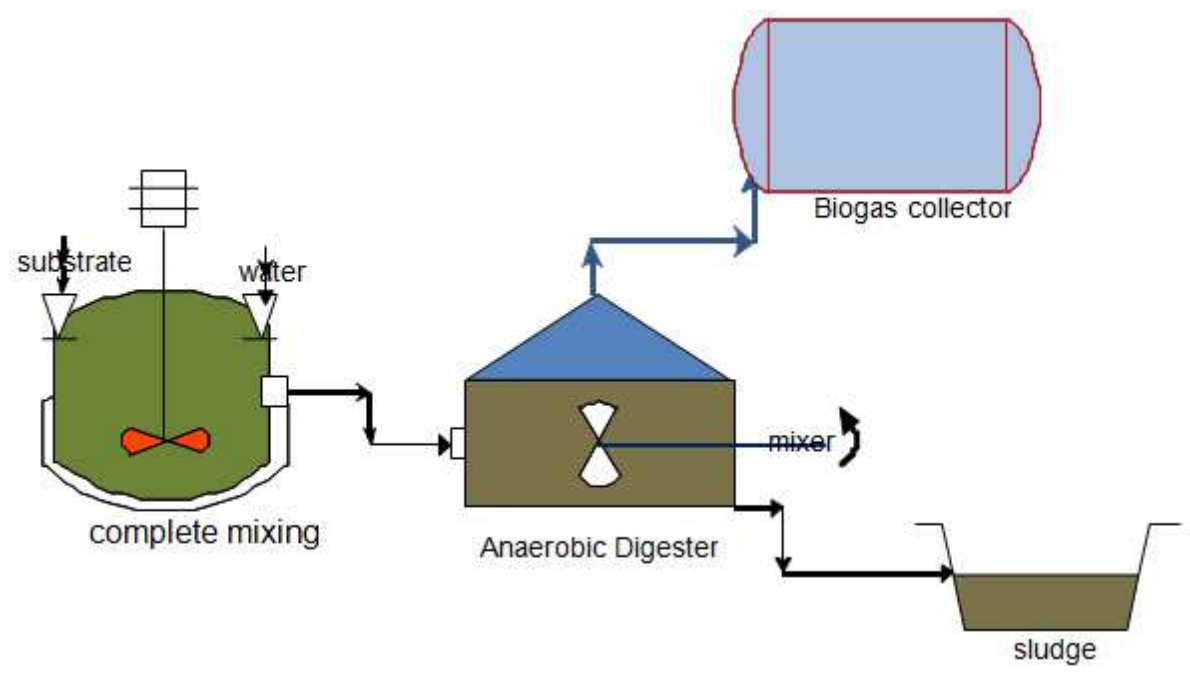

Figure 1. Biogas production flow diagram.

\subsection{Experimental Procedures}

Water bath is the automatic temperature controller machine by water. The water bath was adjusted at Mesophilic range (temperature of $40^{\circ} \mathrm{C}$ ).

Substrate characterization: average of total substrate generation:

$\frac{\text { total first data }+ \text { totl second data colleted }(\mathrm{kg})}{2}$

Protein determination:

$$
\% \text { Crude protein }=\% \mathrm{~N} * 6.25
$$

Equation (1) shows crude protein percent determination and constant 6.25 factor rates that multiplied by nitrogen atom in nutrition [16].

Fat determination:

$$
\% \text { Crude fat }=\left(\mathrm{W}_{2}-\mathrm{W}_{1}\right) * 100 / \mathrm{S}
$$

W2 = weight of extraction flask after extraction

$\mathrm{W} 1$ = weight of extraction flask before extraction $\mathrm{S}=$ weight of sample used for extraction

In equation (2) the crude fat is determined by extraction and balancing on the extraction unit operation [17].

Carbohydrate determination:

$$
(\%) \text { Carbohydrate }=[100-(\% \mathrm{P}+\% \mathrm{~F}+\% \mathrm{~A}+\% \mathrm{M})]
$$

Where $\mathrm{P}=\%$ protein; $\mathrm{F}=\%$ fat; $\mathrm{A}=\%$ ash and $\mathrm{M}=\%$ moisture content [18]

Carbohydrate contents also determine using equation 3, and also shows protein, ash, fat and moisture content affects the amount of carbohydrate.

Ash contents:

After burning the sample at $650^{\circ} \mathrm{C}$ for 6 hours in furnace

$$
\mathrm{M}_{\mathrm{d}}-\mathrm{M}_{\mathrm{v}}=\mathrm{M}_{\mathrm{a}}
$$

Where $\mathrm{Md}=$ mass of dried sample 

[19].

$\mathrm{Mv}=$ mass of volatile mater

$\mathrm{M}_{\mathrm{a}}=$ mass of ash

$$
\% \text { ash }=\frac{\text { weight of ash left }}{\text { weight of sample }} * 100
$$

In equation (5) the ash content determination using furnace

$\mathrm{C}$ : $\mathrm{N}$ ratio also calculated using the following mathematical formula

$$
\mathrm{C}: \mathrm{N} \text { ratio }=\frac{\text { Mass of total organic carbon }}{\text { Mass of total kjeldahl Nitrogen }}
$$

$\mathrm{C}=\%$ fat* No $\mathrm{C}^{*}$ mass of $\mathrm{C}+\%$ protein* No $\mathrm{C}^{*}$ mass of $\mathrm{C}$ $+\%$ carbohydrate* No $\mathrm{C}^{*}$ mass of $\mathrm{C}$

$\mathrm{N}=\%$ p ${ }^{*}$ No $\mathrm{N}^{*}$ mass

1. Two plastic bottle digesters with two liters each were prepared.

2. 3.1 liter of Gas collectors (balloons) for each and gas pipe were prepared.

3. 3.5 liter of substrate with proportional inoculums was prepared and $1.75 \mathrm{~L}$ substrate was filled for each plastic bottle digester. And $0.25 \mathrm{~L}$ of the digester volume was free for each. It is continue prepared and adjusted up to iteration completed.

4. The empty balloons were connected the free space top digester by gas pipe.

5. The water bath was filled by water and set adjustment of the temperature at $(25-35)^{\circ} \mathrm{C}$

6. The digesters were inserted in to water bath. And keep up to retention time were completed.

7. The volume of biogas produced was measured at each interval of two days. By insert gas collector in cylindrical water container and the amount of water displace is equal with the amount of gas in the gas collector.

8. For adjustment of $\mathrm{pH}$ the same buffer solution of $\mathrm{Na}$ $(\mathrm{OH})$ were used in the interval of two days, the buffer solution droplets depends on concentration and volume of digester per 2 days for continuously 29 days and droplet of per 2 days for the rest interval days.

\section{Result and Discussion}

\subsection{Experimental Data Collection}

Data (leftover food and solid kitchen waste) was collected for two weeks continuously.

The data collected and measured with weight measuring balance, to know the total leftover food and solid kitchen wastes generated from JiT, and also meal profile index determined by percent (figures $2-4$, Tables $1-4$ ).

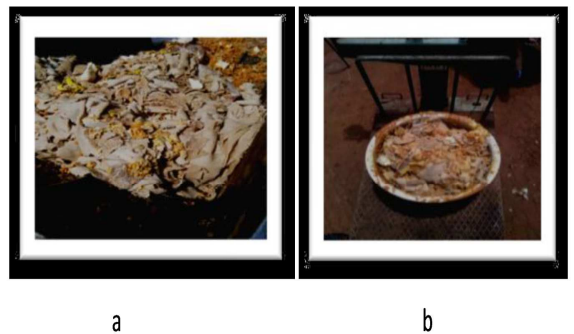

Figure 2. Leftover food from student dining hall; (a, shows leftover food in garbage. $b$, shows leftover daily measuring).

\begin{tabular}{|c|c|c|c|}
\hline Date & Leftover food & Total leftover food in $\mathrm{kg}$ & Total leftover food in $\mathrm{kg} / \mathrm{day}$ \\
\hline \multirow{4}{*}{ Monday } & Breakfast: rise with bread & 120 & \\
\hline & Lunch: shero wot by enjera & 320 & 870 \\
\hline & Dinner: cheese bee by enjera & 430 & \\
\hline & Breakfast: rise & 121 & \\
\hline \multirow[t]{3}{*}{ Tuesday } & Lunch: cheese bee wot by enjera & 306 & 934 \\
\hline & Dinner: meat wot by enjera & 507 & \\
\hline & Breakfast: kinche & 140 & \\
\hline \multirow[t]{3}{*}{ Wednesday } & Lunch: cheese bee wot by enjera & 316 & 776 \\
\hline & Dinner: cheese bee wot by enjera & 320 & \\
\hline & Breakfast: enjera firfir & 97 & \\
\hline \multirow[t]{3}{*}{ Thursday } & Lunch: potato with meat by enjera & 382 & 834 \\
\hline & Dinner: cheese bee wot by enjera & 355 & \\
\hline & Breakfast: rise by bread & 152 & \\
\hline \multirow[t]{3}{*}{ Friday } & Lunch: cheese bee wot by enjera & 323 & 848 \\
\hline & Dinner: cheese bee wot by enjera & 373 & \\
\hline & Breakfast: rise by bread & 134 & \\
\hline \multirow[t]{3}{*}{ Saturday } & Lunch: shiro with vegetable by enjera & 377 & 958 \\
\hline & Dinner: meat wot by enjera & 447 & \\
\hline & Breakfast; enjera firfir & 109 & \\
\hline \multirow[t]{2}{*}{ Sunday } & Lunch: cheese bee wot by enjera & 244 & 643 \\
\hline & Dinner: potato with meat wot by enjera & 290 & \\
\hline In week & Total leftover food & & 5863 \\
\hline In Year & Total leftover food in ten months & & $10 * 4 * 5863=234520$ \\
\hline
\end{tabular}

Table 1. First data collected (leftover food at first data colleting) 
Table 2. Second data collection (second measuring for accuracy).

\begin{tabular}{|c|c|c|c|}
\hline Date & Leftover food & Total leftover food in $\mathrm{kg}$ & Total leftover food in $\mathrm{kg} / \mathrm{day}$ \\
\hline \multirow{4}{*}{ Monday } & Breakfast: rise with bread & 125 & \\
\hline & Lunch: shero wot by enjera & 325 & 875 \\
\hline & Dinner: cheese bee by enjera & 425 & \\
\hline & Breakfast: rise & 125 & \\
\hline \multirow[t]{3}{*}{ Tuesday } & Lunch: cheese bee wot by enjera & 310 & 945 \\
\hline & Dinner: meat wot by enjera & 510 & \\
\hline & Breakfast: kinche & 144 & \\
\hline \multirow[t]{3}{*}{ Wednesday } & Lunch: cheese bee wot by enjera & 320 & 779 \\
\hline & Dinner: cheese bee wot by enjera & 315 & \\
\hline & Breakfast: enjera firfir & 98 & \\
\hline \multirow[t]{3}{*}{ Thursday } & Lunch: potato with meat by enjera & 388 & 836 \\
\hline & Dinner: cheese bee wot by enjera & 350 & \\
\hline & Breakfast: rise by bread & 150 & \\
\hline \multirow[t]{3}{*}{ Friday } & Lunch: cheese bee wot by enjera & 325 & 835 \\
\hline & Dinner: cheese bee wot by enjera & 360 & \\
\hline & Breakfast: rise by bread & 140 & \\
\hline \multirow[t]{3}{*}{ Saturday } & Lunch: shiro with vegetable by enjera & 370 & 960 \\
\hline & Dinner: meat wot by enjera & 450 & \\
\hline & Breakfast; enjera firfir & 120 & \\
\hline \multirow[t]{2}{*}{ Sunday } & Lunch: cheese bee wot by enjera & 240 & 660 \\
\hline & Dinner: potato with meat wot by enjera & 300 & \\
\hline In week & Total leftover food & & 5890 \\
\hline In Year & Total leftover food in ten months & & $10 * 4 * 5890=235600$ \\
\hline
\end{tabular}

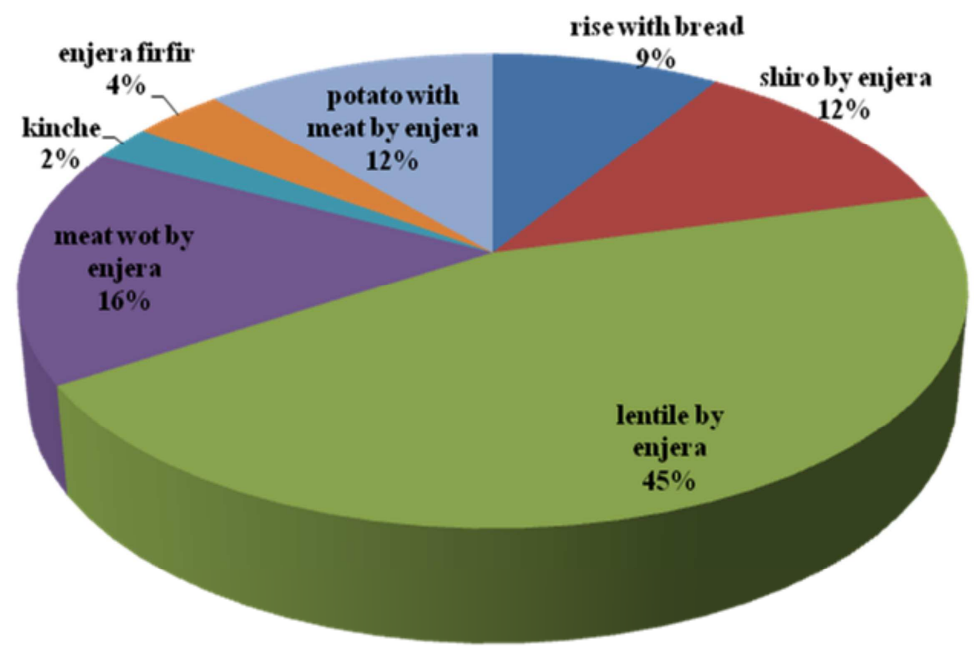

Figure 3. Chart of leftover food composition (Is shows that the student meal profile in jimma university).

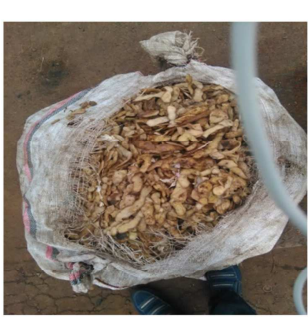

a

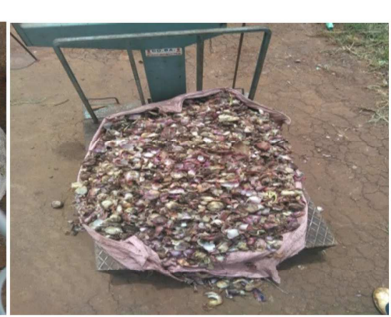

b
- POTATO PEEL —ONION PEEL

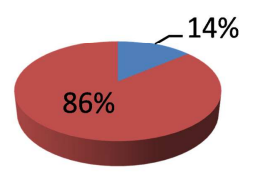

C

Figure 4. Solid kitchen waste measuring (a, shows the potato peel and b, is the onion peels and they are the basic solid kitchen waste constituents, $c$, indicates that the percent representation of the basic kitchen wastes). 
Table 3. First data collected solid kitchen wastes.

\begin{tabular}{llll}
\hline Date & Kitchen food type & Total kitchen waste in $\mathbf{k g}$ & Total kitchen waste in kg /day \\
\hline \multirow{3}{*}{ Monday } & Breakfast: onion peel & 21 & 108 \\
& Lunch: onion peel & 42 & \\
Tuesday & Dinner: onion peel & 45 & 133 \\
& Breakfast: onion peel & 22 & \\
Wednesday & Lunch: onion peel & 44 & 150 \\
& Dinner: onion peel & 67 & \\
Breakfast: onion peel & 30 & 138 onion peel \\
Thursday & Lunch: onion peel & 50 & And \\
& Dinner: onion peel & 70 & 80 potato peel \\
& Breakfast: onion peel & 29 & \\
Friday & Potato peel for lauch & 80 & 153 \\
& Lunch: onion peel & 67 & \\
Saturday & Dinner: onion peel & 42 & 183 \\
& Breakfast: onion peel & 24 & \\
& Lunch: onion peel & 74 & 175 onion peel \\
Sunday & Dinner: onion peel & 55 & And \\
& Breakfast: onion peel & 34 & 95 potato peel \\
In week & Lunch: onion peel & 76 & 1215 \\
I year & Dinner: onion peel & 73 & $10^{*} 4 * 1215=48600$ \\
\hline
\end{tabular}

Table 4. Second solid kitchen wastes data collected (second data measuring for accuracy).

\begin{tabular}{|c|c|c|c|}
\hline Date & Kitchen food type & Total kitchen waste in kg & Total kitchen waste in $\mathrm{kg}$ /day \\
\hline \multirow{3}{*}{ Monday } & Breakfast: red onion & 22 & \multirow{3}{*}{119} \\
\hline & Lunch: red onion & 47 & \\
\hline & Dinner: red onion & 50 & \\
\hline \multirow{3}{*}{ Tuesday } & Breakfast: red onion & 20 & \multirow{3}{*}{130} \\
\hline & Lunch: red onion & 40 & \\
\hline & Dinner: red onion & 70 & \\
\hline \multirow{3}{*}{ Wednesday } & Breakfast: red onion & 35 & \multirow{3}{*}{159} \\
\hline & Lunch: red onion & 55 & \\
\hline & Dinner: red onion & 69 & \\
\hline \multirow{4}{*}{ Thursday } & Breakfast: red onion & 25 & \multirow{4}{*}{$\begin{array}{l}136 \text { onion peel } \\
\text { And } \\
75 \text { potato peel }\end{array}$} \\
\hline & Potato peel for lauch & 75 & \\
\hline & Lunch: red onion & 63 & \\
\hline & Dinner: red onion & 48 & \\
\hline \multirow{3}{*}{ Friday } & Breakfast: red onion & 28 & \multirow{3}{*}{161} \\
\hline & Lunch: red onion & 66 & \\
\hline & Dinner: red onion & 67 & \\
\hline \multirow{3}{*}{ Saturday } & Breakfast: red onion & 33 & \multirow{3}{*}{183} \\
\hline & Lunch: red onion & 70 & \\
\hline & Dinner: red onion & 65 & \\
\hline \multirow{4}{*}{ Sunday } & Breakfast: red onion & 35 & \multirow{4}{*}{$\begin{array}{l}188 \text { onion peel } \\
\text { And } \\
96 \text { potato peel }\end{array}$} \\
\hline & Lunch: red onion & 78 & \\
\hline & Potato peel for dinner & 96 & \\
\hline & Dinner: red onion & 75 & \\
\hline In week & Total kitchen waste over & & 1247 \\
\hline I year & Total kitchen waste over & & $10 * 4 * 1247=49880$ \\
\hline
\end{tabular}

Figure 2 Leftover food from student dining hall; (a, shows leftover food in garbage. b, shows leftover daily measuring). Average two weeks leftover food data $5876.5 \mathrm{~kg} /$ week. $5876.5 \mathrm{~kg}$ amount of leftover food can be disposed per week on the open land surface that causes the problem of environmental pollution. Average two weeks solid kitchen waste data $1231 \mathrm{~kg} /$ week. $1231 \mathrm{~kg}$ amount of solid kitchen waste can be disposed per week on open land surface that causes environmental pollution. The total leftover food and solid kitchen waste in week was $7107.5 \mathrm{~kg} /$ week

From proximate and ultimate analysis of solid kitchen waste and leftover food for determination of fat, protein, carbohydrate, ash and $\mathrm{C} / \mathrm{N}$ ratio 
Ash: After burning at $650^{\circ} \mathrm{C}$ for 6huors in furnace, from $15.72 \mathrm{~g}$ of solid the ash is only $1.729 \mathrm{~g}$, and $\mathrm{ash} \%$ was $11.6 \%$

By nutritional analysis; Where $\mathrm{F}$ is fat, $\mathrm{P}$ is protein, $\mathrm{A}$ is ash, and $\mathrm{M}$ is moisture content of dry base:- $\mathrm{F}=7 \%, \mathrm{P}$ $=15.625 \%, \mathrm{~A}=11.6 \%, \mathrm{M}=4.5 \%, \%$ carbohydrate $=$ $60.27 \%$

In this experimental determination of nutritional analysis carbohydrate highest component when compared with other nutritional component, protein is the highest next to the carbohydrate. Therefore the substrate experimental results, high carbohydrate contents so faster consumed during anaerobic fermentation (figure 5).

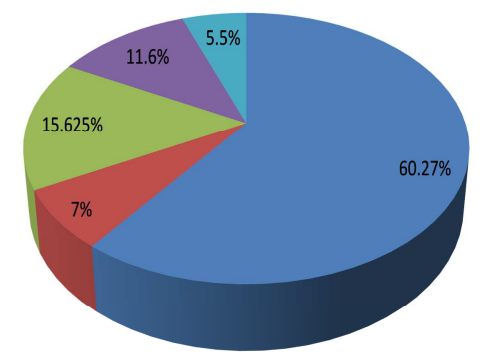

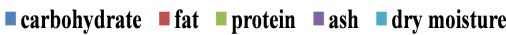

Figure 5. Substrate percent composition which shows that mixed of kitchen and leftover food, by nutrients and proximate analysis.

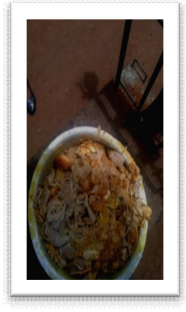

a

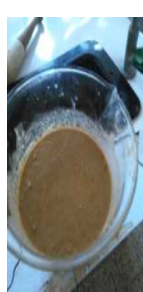

b

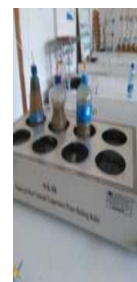

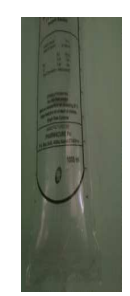

d

Table 5. Basic nutrients composition and chemical formula.

\begin{tabular}{ll}
\hline Substrate & chemical composition \\
\hline Fat & $\mathrm{C}_{15} \mathrm{H}_{31} \mathrm{COOH}$ \\
Protein & $\mathrm{C}_{4} \mathrm{H}_{6} \mathrm{ON}$ \\
Carbohydrate & $\mathrm{C}_{6} \mathrm{H}_{12} \mathrm{O}_{6}$ \\
\hline
\end{tabular}

Total mass of carbon in the sample depending molecular formula of nutrients in (table 5):

$\mathrm{C}=64.33 \mathrm{~g} / \mathrm{mol}$ and $\mathrm{N}=2.1875 \mathrm{~g} / \mathrm{mol}$, the $\mathrm{C} / \mathrm{N}$ ratio was 29.4. So it was in the range of allowable ratio $(21: 1-30: 1$ is the result of experimental work and is less when compare with the previous work $\mathrm{C}$ : $\mathrm{N}$ is 31.65 [15]

\subsection{Parameter Adjusted and Result Outcomes Digester}

The food and kitchen wastes were weighted using weight measuring instrument. Homogenised the wastes and diluted with proportional at dilution rate of 1: 1.5 with water. Checked the composition ( $\mathrm{C} / \mathrm{N}$ ratio is $20: 1$ to $30: 1)$ [13]. The calculated from experiment is 29.4, which is in the standard range [20]. The $\mathrm{pH}$ of solution (slurry) adjusted at standard production $(\mathrm{pH} 4.5$ - 7, at the temperature of Mesophilic range $\left(25-40^{\circ} \mathrm{C}\right)$. Input prepared substrate into an aerobic Digester tank (batch reactor), and kept it until reaction time completed (residence time or hydraulic retention time 20 - 30 days), it was 29days. From Experimental results, collect top products or biogas to gas collector and measure appropriately (figure 6: d, e, f and g). $3.3 \mathrm{~L}$ of biogas where collected from each $1.5 \mathrm{~L}$ substrate in parallel digesters though 29 days (table 6 and figure $8 a$ ).

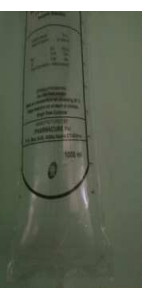

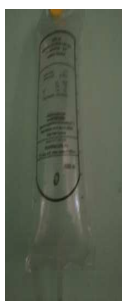

$\mathrm{f}$

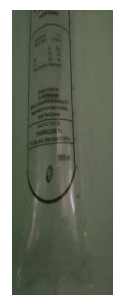

g

Figure 6. Over all procedure of experimental production.

(a, sample measurement, b sample homogenize with proportional dilution rate, $\mathrm{c}$, digester setup with buffering, $\mathrm{d}$, gas production at the end of 7 days, e,

gas production at the end of 14days, $\mathrm{f}$, gas production at the end of 21 days, $\mathrm{g}$, gas production at the end of 29days).

Table 6. Gas production rate with the detention time of Mesophilic range.

\begin{tabular}{lllllllllllll}
\hline Average Gas (1) & 0 & 0.4 & 0.75 & 1.4 & 1.75 & 2.1 & 2.55 & 2.8 & 2.95 & 3.0 & 3.07 & 3.32 \\
Time (days) & 1 & 3 & 5 & 7 & 9 & 11 & 13 & 15 & 17 & 19 & 21 & 29 \\
\hline
\end{tabular}

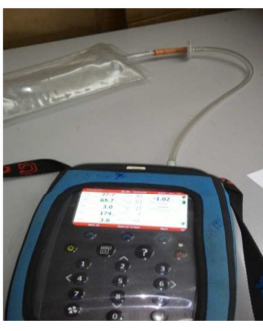

${ }_{1 \%}^{02}$ Biogas composition ${ }_{\mathrm{H} 2 \mathrm{~S}}$

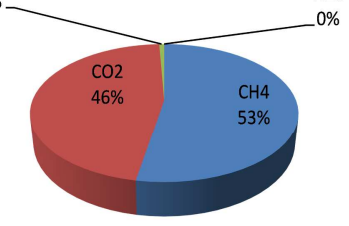

Figure 7. Gas composition analysis,(a, Portable biogas analyzer to detect and analyze hazardous concentrations of biogas, b, average percent composition of biogas gas). 


\subsection{Gas Composition Analysed}

The biogas quality was analyzed by biogas analyzer. The biogas quality was depends on the gas components [21]. If the composition of methane is maximum biogas considered as high quality because of flammability and combustibility of biogas depends on methane composition [22].

The result also analyzed using biogas analyzer in each term and run, as shown in figure 7 which gives the gas composition listed in.

From the table 7 we have seen that three factor changing and minimum two repetitions, the output results also change accordingly. Depending on the factor changing and result output, there was model development for optimization using design expert, central composite method.

Table 7. Experimental biogas analysis iterations and results.

\begin{tabular}{llllllll}
\hline Runs & Temp. $\left({ }^{\circ} \mathbf{C}\right)$ & $\mathbf{p H}$ & $\begin{array}{l}\text { Time } \\
(\mathbf{d a y})\end{array}$ & $\mathbf{C H}_{\mathbf{4}}(\mathbf{\%})$ & $\begin{array}{l}\mathbf{C O}_{2} \\
(\mathbf{\%})\end{array}$ & $\begin{array}{l}\mathbf{O}_{2} \\
(\mathbf{\%})\end{array}$ & Volume (I) \\
\hline 1 & 35.0 & 5.5 & 21 & 55.7 & 40 & 0.5 & 3 \\
2 & 25.0 & 6 & 7 & 37 & 60 & 1.2 & 1 \\
3 & 25.0 & 5 & 7 & 32 & 62 & 1 & 1 \\
\hline
\end{tabular}

\begin{tabular}{llllllll}
\hline Runs & Temp. $\left({ }^{\circ} \mathbf{C}\right)$ & $\mathbf{p H}$ & $\begin{array}{l}\text { Time } \\
(\mathbf{d a y})\end{array}$ & $\mathbf{C H}_{\mathbf{4}}(\mathbf{\%})$ & $\begin{array}{l}\mathbf{C O}_{2} \\
(\mathbf{\%})\end{array}$ & $\begin{array}{l}\mathbf{O}_{2} \\
(\%)\end{array}$ & Volume (l) \\
\hline 4 & 35.0 & 5.5 & 21 & 59 & 42 & 0.57 & 3 \\
5 & 35.0 & 5.5 & 21 & 58 & 43 & 0.56 & 3 \\
6 & 30.0 & 5 & 14 & 52 & 43 & 0.65 & 2 \\
7 & 30.0 & 5 & 14 & 50 & 43 & 0.7 & 2 \\
8 & 34.0 & 5.5 & 21 & 57 & 38 & 0.65 & 3 \\
9 & 37.0 & 6.3 & 29 & 62 & 35 & 0.34 & 3.3 \\
10 & 30.0 & 6.3 & 14 & 54 & 43 & 0.6 & 2 \\
11 & 25.0 & 5 & 29 & 61 & 38 & 0.45 & 3.3 \\
12 & 25.0 & 6.3 & 7 & 35 & 61 & 1.4 & 1 \\
13 & 30.0 & 4.6 & 21 & 54 & 30 & 0.67 & 3 \\
14 & 40.0 & 5.5 & 7 & 38 & 60 & 1.3 & 1 \\
15 & 30.0 & 6 & 21 & 59 & 32 & 0.7 & 3 \\
16 & 40.0 & 6.3 & 29 & 61 & 28 & 0.45 & 3.3 \\
17 & 25.0 & 4.6 & 14 & 50 & 48 & 0.56 & 2 \\
18 & 40.0 & 4.6 & 29 & 63 & 28 & 0.4 & 3.3 \\
\hline
\end{tabular}

From the experimental result table 8 shows the biogas quality increases with in retention time increases (figure $8 \mathrm{~b}$ ). And also there were decreasing of $\mathrm{CO}_{2}$ and $\mathrm{O}_{2}$ production through the retention time (figure $8 \mathrm{c}, \mathrm{d}$ ).

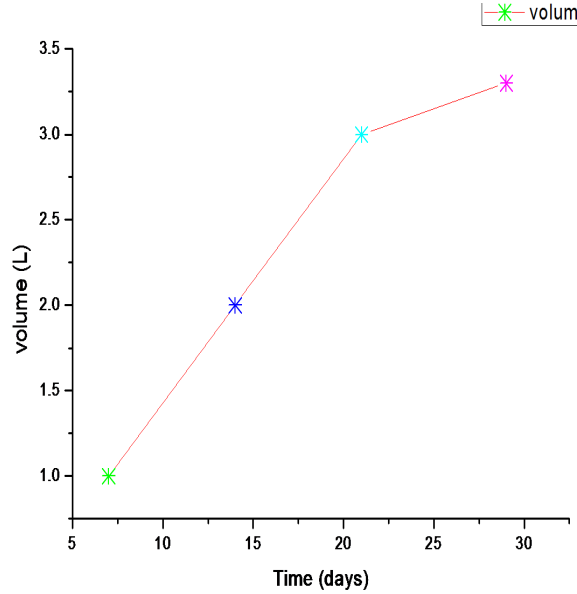

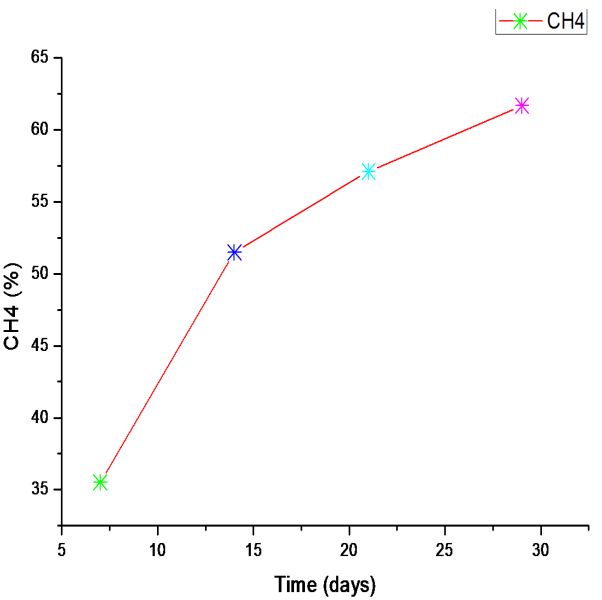

b

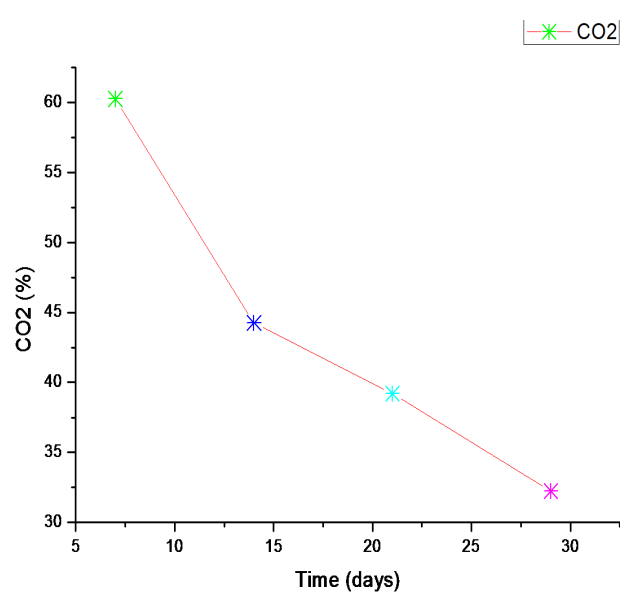

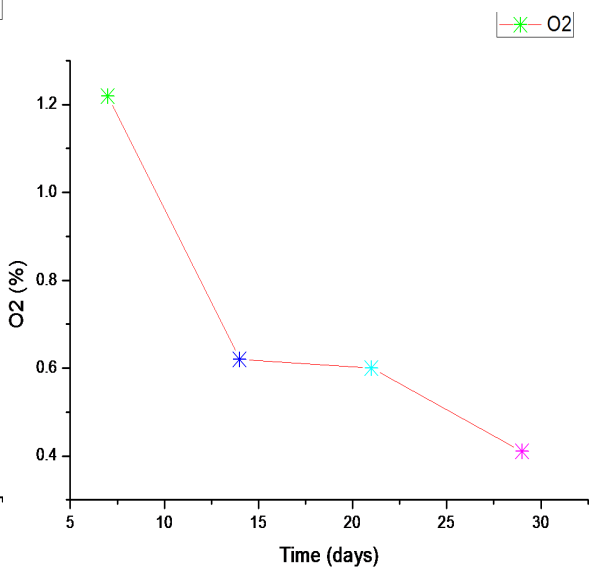

d

Figure 8. Biogas quantity and quality determination with time (days). (a, shows the volume of biogas with time (L) generated in the interval of days; $b$, methane content increment in biogas generation $c, d, \mathrm{CO}_{2}$ and $\mathrm{O}_{2}$ decrement in biogas with volume and methane increment). 
Table 8. Average gas product quality analysis in reactor.

\begin{tabular}{|c|c|c|c|c|c|c|c|}
\hline Time (days) & Gas volume (I) & $\mathrm{pH}$ & Temp $\left({ }^{\circ} \mathrm{C}\right)$ & $\mathrm{CH}_{4}(\%)$ & $\mathrm{CO}_{2}(\%)$ & $\mathrm{O}_{2}(\%)$ & $\mathrm{H}_{2} \mathrm{~S}(\%)$ \\
\hline 7 & 1 & 5.7 & 28.75 & 35.5 & 62.75 & 1.22 & 0.00002 \\
\hline 14 & 2 & 5.23 & 28.75 & 52.5 & 46.25 & 0.63 & 0.00003 \\
\hline 21 & 3 & 5.2 & 33.2 & 59.12 & 39.5 & 0.6 & 0.00056 \\
\hline Average & 2.325 & 5.23 & 31.55 & 52.5 & 46.2 & 0.71 & 0.0002 \\
\hline
\end{tabular}

From table 9 there were analysis of constraints according to the targets and goals. In the ranges of variables or factors there were maximum and minimum result output values using Optimization methane by design expert software central composite method

Table 9. Constraints

\begin{tabular}{|c|c|c|c|c|c|c|}
\hline Name & Goal & Lower Limit & Upper Limit & Lower Weight & Upper Weight & Importance \\
\hline Temperature & in range & 25.0 & 40.0 & 1.00 & 1.00 & 3 \\
\hline $\mathrm{pH}$ & in range & 4.6 & 6.3 & 1.00 & 1.00 & 3 \\
\hline Time & In rang & 7.00 & 29.0 & 1.00 & 1.00 & 3 \\
\hline $\mathrm{CO}_{2}$ & Minimize & 28 & 62 & 1.00 & 1.00 & 3 \\
\hline $\mathrm{O}_{2}$ & Minimize & 0.34 & 1.4 & 1.00 & 1.00 & 3 \\
\hline Volume & Maximize & 1 & 3.3 & 1.00 & 1.00 & 3 \\
\hline
\end{tabular}

The target where maximizing $\mathrm{CH}_{4}$ and volume, minimizing $\mathrm{CO}_{2}, \mathrm{O}_{2}$, by balancing these output values, the order of 10 alternative solutions desirability listed in table 10 .

Table 10. Solutions.

\begin{tabular}{lllllllll}
\hline Number & Temperature & $\mathbf{p H}$ & Time & $\mathbf{C H}_{\mathbf{4}}$ & $\mathbf{C O}_{\mathbf{2}}$ & $\mathbf{O}_{\mathbf{2}}$ & Volume & Desirability \\
\hline 1 & 26.1 & 5.51 & 29.0 & 63.3 & 27.9 & 0.316 & 3.35 & 1.00 \\
2 & 25.9 & 5.57 & 29.0 & 64.2 & 28.0 & 0.319 & 3.34 & 1.00 \\
3 & 25.0 & 5.58 & 29.0 & 65.4 & 28.0 & 0.316 & 3.32 & 1.00 \\
4 & 25.2 & 5.41 & 28.9 & 63.5 & 27.8 & 0.305 & 3.34 & 1.00 \\
5 & 25.0 & 5.34 & 28.8 & 63.2 & 27.9 & 0.305 & 3.34 & 1.00 \\
6 & 25.1 & 5.34 & 28.8 & 63.1 & 27.9 & 0.305 & 3.34 & 1.00 \\
7 & 26.0 & 5.46 & 29.0 & 63.0 & 27.8 & 0.311 & 3.35 & 1.00 \\
8 & 40.0 & 4.60 & 28.3 & 62.8 & 28.0 & 0.312 & 3.31 & 0.998 \\
9 & 25.0 & 5.30 & 28.3 & 63.0 & 28.5 & 0.319 & 3.33 & 0.996 \\
10 & 40.0 & 5.10 & 29.0 & 60.5 & 27.9 & 0.330 & 3.43 & 0.979 \\
\hline
\end{tabular}

Number of Starting Points 10

\begin{tabular}{|c|c|c|}
\hline Temperature & pH & Time \\
\hline 28.9 & 5.72 & 20.5 \\
\hline 29.9 & 6.24 & 24.7 \\
\hline 28.9 & 5.80 & 10.8 \\
\hline 27.1 & 5.16 & 15.2 \\
\hline 29.7 & 4.74 & 8.10 \\
\hline 35.4 & 5.50 & 28.3 \\
\hline 33.6 & 5.00 & 20.5 \\
\hline 31.5 & 5.40 & 13.9 \\
\hline 25.2 & 5.40 & 11.9 \\
\hline 35.6 & 5.06 & 13.8 \\
\hline
\end{tabular}

Final Equation in Terms of Coded Factors:

$$
\text { volume }=2.68+0.0160 * \mathrm{~A}+0.0306 * \mathrm{~B}+1.20 * \mathrm{C}-0.0187 * \mathrm{~A}^{2}-0.120 * \mathrm{~B}^{2}-0.469 * \mathrm{C}^{2}+0.0365 * \mathrm{~A} * \mathrm{~B}+0.0386 * \mathrm{~A} * \mathrm{C}-
$$

Equation (7) is model equation, that determination biogas volume using design expert central composite method coded factor.

Final Equation in Terms of Actual Factors:

Volume $=-5.59-0.0158 *$ temperature $+1.80 * \mathrm{pH}+0.278^{*}$ Time $-0.000333^{*}$ temperature ${ }^{2}-0.166^{*} \mathrm{pH}^{2}-0.00388^{*} \mathrm{Time}^{2}+$ $0.00572 *$ temperature $* \mathrm{pH}+0.000468 *$ temperature $*$ Time $-0.00805 * \mathrm{pH} *$ Time

Equation (8) is model equation, that determination biogas volume using design expert central composite method actual 
factor.

Final Equation in Terms of Coded Factors:

$$
\mathrm{CH}_{4}=54.6+0.285 * \mathrm{~A}+0.791 * \mathrm{~B}+13.0 * \mathrm{C}+3.95 * \mathrm{~A}^{2}+1.71 * \mathrm{~B}^{2}-9.43 * \mathrm{C}^{2}-4.26 * \mathrm{~A} * \mathrm{~B}-2.32 * \mathrm{~A} * \mathrm{C}+3.10 * \mathrm{~B} * \mathrm{C}
$$

Equation (9) is model equation, that determination methane content of biogas using design expert central composite method coded factor

Final Equation in Terms of Actual Factors:

$$
\begin{array}{r}
\mathrm{CH}_{4}=43.9-0.378 * \text { temperature }-9.09 * \mathrm{pH}+3.10 * \text { Time }+0.0702 * \text { temperature }{ }^{2}+2.3 * \mathrm{pH}^{2}-0.0780 * \mathrm{Time}^{2}-0.668 * \\
\text { temperature } * \mathrm{pH}-0.0282 * \text { temperature } * \text { Time }+0.332 * \mathrm{pH} * \text { Time }
\end{array}
$$

Equation (10) is model equation, that determination methane content of biogas using design expert central composite method actual factor.

According to the date analysis by design expert software, central composite method, the design model equation generates with respect to factors, thus equation (10) is optimum operation design equation.

Increasing the quantity of methane increases heat value of biogas [23]. In other way increase quantities of carbon dioxide in biogas, decrease heat value of biogas [24]. Average value methane $(50-70 \%)$ and carbon dioxide $(25-$ $45 \%$ ) [25]. From the experimental result the biogas quality increases with in retention time increases. From experimental result of biogas productions, the quality of biogas analysed by the machine of biogas analysers, reads the compound in biogas products on the screen. $\mathrm{A} \mathrm{CH}_{4}$ component increases from 35.5 to $62.75 \%$ from 7 to 29 days, in average $52.5 \%$ $\mathrm{CH}_{4}$ though digesters. $\mathrm{CO}_{2}$ gas decreases from 63 to $32.25 \%$ from 7 to 29 days, in average $43.7 \%$ and there is no significance $\mathrm{O}_{2}$ that is $0.71 \%$ in average and $20 \mathrm{ppm}$ of $\mathrm{H}_{2} \mathrm{~S}$ through digesters (table 8 and figure $7 \mathrm{~b}$ ).

In the alternative solution optimization $\mathrm{CH}_{4}$ ranges from $60.5 \%$ to $65.4 \%, \mathrm{CO}_{2} 27.8$ to $28 \%$, at temperature range 25 to $40^{\circ} \mathrm{C}$, pH 4.6 ton 5.58 , time range 28 to 29 days. They methane phase takes place after 36th days, $\mathrm{CH}_{4}$ and $\mathrm{CO}_{2}$ production was stabilized with proportions respectively between $57 \%$ and $32-42 \%$ [15]. The gap shows that the raw material difference the municipal solid waste and food wastes which physical and chemical properties of raw material is one of factor that affects the quality of biogas production.

The low biogas quality was resulted from this experimental biogas production. Two measure assumptions that affect biogas quality in this experimental design.

The first free space left of in each digester: at the free space of digester actually occupied by atmospheric gases that more oxygen presence in, where the oxygen presence in the substrate, the reaction becomes aerobic digestion, resulting aerobic fermentative produces carbon dioxide and alcohol at the first around 7days. More amount of carbon dioxide was produced until the oxygen in free digester is completely consumed. In high percent amount of methane was produced after the oxygen in the free space of digester completely consumed.

Substrate type: the majority or almost all the substrate type was carbohydrate even if kitchen waste were mixed with leftover food, high amount of carbohydrate were exists. But the production rate was fast considering the other type of food waste.

The quality of biogas production depends on the substrate type. Highest amount of methane composition produced in biogas, if the substrate composition highest in lipid compared with protein and carbohydrate. And protein is the second for the biogas quality production next to lipid but it takes a time to degraded compared to other [26].

Therefore depending on the experimental biogas production design, two justifications could adjust the biogas quality production.

Remove the air from free space of digester and create vacuum, the reaction starts anaerobic fermentative.

Collecting biogas production after 6days started production, the major components of biogas before 6days were carbon dioxide.

\section{Conclusion}

Leftover food and solid kitchen waste is the major component of organic municipal solid waste that cause environmental pollution. For this pollution, anaerobic digestion results biogas and natural fertilizer is the way of the waste management and sustainable development. The total mixed leftover food and solid kitchen waste collected $7107.5 \mathrm{~kg}$ per week contains $60.27 \%$ carbohydrate $15.625 \%$ protein and $7 \%$ fat. From experimental biogas production and optimization, 3.3L biogas produced from $1.75 \mathrm{~L}$ substrate prepared with low biogas quality which contains about 52\% methane, $46 \%$ of carbon dioxide and the others are trace compounds. The biogas quality was depends on the gas components. If the composition of methane is maximum biogas considered as high quality because of flammability and combustibility of biogas depends on methane composition. And also the quality parameter determination is one of biogas optimization; from software analysis the quality model equation formulated and became optimized. Depending on the current condition (range of temperature, $\mathrm{Ph}$, and retention time) model equations of optimization were developed for gas volume and $\mathrm{CH}_{4} \%$ using design expert software central composite method. The low quality of biogas resulted from experimental and software analysis were formulated from two assumptions (substrate type and free space that leaves in each digesters) in substrate characterization low volatile mater, and this resulted low fat component and $\mathrm{C} / \mathrm{N}$ ratio 29.4: 1 , maximum $\mathrm{C} / \mathrm{N}$ ratio 30: 1 . From the experimental result $\mathrm{C} / \mathrm{N}$ ratio was high which 
shows high Carbon content and low Nitrogen content in sample. It suggested that extremely increment of $\mathrm{C} / \mathrm{N}$ ratio results low $\mathrm{CH}_{4} \%$. The second suggested of the result of low quality of biogas was leaving free space in digester which oxygen presence, if there, the reaction become aerobic rather than anaerobic resulted more $\mathrm{CO}_{2}$ rather than $\mathrm{CH}_{4}$. And also the volume of biogas maximized formed using model analysis.

\section{Recommendation}

Depending on the output result and constraints it recommended that temperature, $\mathrm{pH}$ and detention time are the main factors that determine the quality as well as the quantity of biogas production in addition to substrate constituents. According the experimental output and model development, it is critical experimental results and is good optimization model for specified substrate. And it is better to use this model equation for large biogas production in such substrate types.

\section{References}

[1] Bekun FV, Alola AA, Sarkodie SA. Toward a sustainable environment: Nexus between $\mathrm{CO}_{2}$ emissions, resource rent, renewable and nonrenewable energy in 16-EU countries. Science of the Total Environment. 2019; 657: 1023-9.

[2] Naqvi SR, Jamshaid S, Naqvi M, Farooq W, Niazi MBK, Aman Z, et al. Potential of biomass for bioenergy in Pakistan based on present case and future perspectives. Renewable and Sustainable Energy Reviews. 2018; 81: 1247-58.

[3] Rahman MM, Lee YS, Tamiri FM, Hong MGJ. Anaerobic Digestion of Food Waste. Anaerobic Digestion Processes: Springer; 2018. p. 105-22.

[4] Fitamo T, Treu L, Boldrin A, Sartori C, Angelidaki I, Scheutz C. Microbial population dynamics in urban organic waste anaerobic co-digestion with mixed sludge during a change in feedstock composition and different hydraulic retention times. Water research. 2017; 118: 261-71.

[5] Tufaner F, Avşar Y. Effects of co-substrate on biogas production from cattle manure: a review. International journal of environmental science and technology. 2016; 13 (9): 230312 .

[6] Tian Y, Zhang H, Chai Y, Wang L, Mi X, Zhang L, et al. Biogas properties and enzymatic analysis during anaerobic fermentation of Phragmites australis straw and cow dung: influence of nickel chloride supplement. Biodegradation. 2017; 28 (1): 15-25.

[7] Franco B, Mahieu E, Emmons L, Tzompa-Sosa Z, Fischer E, Sudo K, et al. Evaluating ethane and methane emissions associated with the development of oil and natural gas extraction in North America. Environmental Research Letters. 2016; 11 (4): 044010.

[8] Angelidaki I, Treu L, Tsapekos P, Luo G, Campanaro S, Wenzel $\mathrm{H}$, et al. Biogas upgrading and utilization: current status and perspectives. Biotechnology advances. 2018; 36 (2): 452-66.
[9] Sun Q, Li H, Yan J, Liu L, Yu Z, Yu X. Selection of appropriate biogas upgrading technology-a review of biogas cleaning, upgrading and utilisation. Renewable and Sustainable Energy Reviews. 2015; 51: 521-32.

[10] Mboowa D, Quereshi S, Bhattacharjee C, Tonny K, Dutta S. Qualitative determination of energy potential and methane generation from municipal solid waste (MSW) in Dhanbad (India). Energy. 2017; 123: 386-91.

[11] Murugan N, Appavu P. Investigation on low temperature biogas generation. International Journal of Ambient Energy. 2018: 1-3.

[12] Latha K, Velraj R, Shanmugam P, Sivanesan S. Mixing strategies of high solids anaerobic co-digestion using food waste with sewage sludge for enhanced biogas production. Journal of cleaner production. 2019; 210: 388-400.

[13] Dioha I, Ikeme C, Nafi'u T, Soba N, Yusuf M. Effect of carbon to nitrogen ratio on biogas production. International Research Journal of Natural Sciences. 2013; 1 (3): 1-10.

[14] Fitamo T, Boldrin A, Boe K, Angelidaki I, Scheutz C. Codigestion of food and garden waste with mixed sludge from wastewater treatment in continuously stirred tank reactors. Bioresource technology. 2016; 206: 245-54.

[15] M Nikiema NB, MK Somda. OPTIMIZATION OF BIOGAS PRODUCTION FROM ORGANIC FRACTION OF MUNICIPAL SOLID WASTE: EXPERIMENTAL TEST USING LIQUID FROM WASTE FERMENTATION. researchgate. $2017 ; 18(2): 211-22$.

[16] Dorbane Z, Kadi SA, Boudouma D, Berchiche M, Bannelier C, Gidenne $T$, editors. NUTRITIVE VALUE OF CRUDE OLIVE CAKE (Olea europaea L.) FOR GROWING RABBIT2016.

[17] Oppermann A, Piqueras-Fiszman B, De Graaf C, Scholten E, Stieger M. Descriptive sensory profiling of double emulsions with gelled and non-gelled inner water phase. Food Research International. 2016; 85: 215-23.

[18] Prentice P, Ong KK, Schoemaker MH, van Tol EA, Vervoort $\mathrm{J}$, Hughes IA, et al. Breast milk nutrient content and infancy growth. Acta Paediatrica. 2016; 105 (6): 641-7.

[19] Alzahrani HR, Kumakli H, Ampiah E, Mehari T, Thornton AJ, Babyak CM, et al. Determination of macro, essential trace elements, toxic heavy metal concentrations, crude oil extracts and ash composition from Saudi Arabian fruits and vegetables having medicinal values. Arabian Journal of Chemistry. 2017; 10 (7): 906-13.

[20] Ciccoli R, Sperandei M, Petrazzuolo F, Broglia M, Chiarini L, Correnti A, et al. Anaerobic digestion of the above ground biomass of Jerusalem Artichoke in a pilot plant: Impact of the preservation method on the biogas yield and microbial community. Biomass and bioenergy. 2018; 108: 190-7.

[21] Mihaescu L, Lazaroiu G, Negreanu GP, Pisa I. INFLUENCE OF THE CHARACTERISTICS OF BIOGAS GENERATED IN THE LEATHER INDUSTRY ON COMBUSTION QUALITY. Thermal Science. 2018; 22.

[22] Ghidotti M, Fabbri D, Torri C. Determination of linear and cyclic volatile methyl siloxanes in biogas and biomethane by solid-phase microextraction and gas chromatography-mass spectrometry. Talanta. 2019; 195: 258-64. 
[23] Gholizadeh T, Vajdi M, Rostamzadeh H. Energy and exergy evaluation of a new bi-evaporator electricity/cooling cogeneration system fueled by biogas. Journal of Cleaner Production. 2019.

[24] Valadkhani A, Smyth R, Nguyen J. Effects of primary energy consumption on $\mathrm{CO}_{2}$ emissions under optimal thresholds: Evidence from sixty countries over the last half century. Energy Economics. 2019; 80: 680-90.
[25] Wu N, Moreira C, Zhang Y, Doan N, Yang S, Phlips E, et al. Techno-Economic Analysis of Biogas Production from Microalgae through Anaerobic Digestion. Biogas: IntechOpen; 2019.

[26] Neves L. GE, Oliveira R., and Alves M. M.,... Influence of composition on the biomethanation potential of restaurant waste at mesophilic temperatures. Waste management 2008: 965-72. 